\title{
[1-25]春 日鉱山
}

米 川 冬 郎 $^{1}$

\section{1. 緒䡒}

$1 \cdot 1$ 位置および交通

所在地 鹿児島県枕崎市西鹿篭 6845 番地

枕崎市の西端, 坊津町に接した春日山の中腹で海抜 $90 \mathrm{~m}$ に位置 する。

交通は鹿児島市から鹿児島交通特急バスにより 2 時間40分で枕 崎駅に，さらに坊津線に乗換え約10分で春日に到着する。また鹿 児島空港からは九州自動車経由で約 $100 \mathrm{~km}$, 所要時間 1 時間 10 分である。鉱石の積出港は山許から西方へ約 $6 \mathrm{~km}$ の坊津町坊浦 にある。

\section{$1 \cdot 2$ 沿 革}

明治34年，鉄鉱山として試掘されたが金鉱を発見するにいたつ た。昭和 4 年 4 月，日本鉱業株式会社の所有となり，本格的開発 に着手以来の沿革は第 1 表の通りである。また産金量を第 2 表に 示す。

\section{$1 \cdot 3$ 現 況}

昭和37年までは金鉱としての採掘（坑内掘）に重点を置き，も つぱら高品位鉱の生産に主力を傾注した。しかし春日鉱山株式会 社発足とともに含金珪酸鉱 ( $\mathrm{Au} 2 \sim 3 \mathrm{~g} / \mathrm{t}$ ，遊離珪酸 $88 \%$ 以上) の生産に切替え，採掘法も露天掘に変更した。

販壳先は日本鉱業 (株) 佐賀関製鍊所，三菱金属(株) 直島製鍊所 等で販売量は銅製鍊の操業度に大きく影警を受ける。

5 ケ年間の生産量を第 3 表に，組織人員を第 2 困に示す。

\section{2. 地筷鉱床の概要}

当地域の地質は中生代の四万十層群を基盤とし，その上に堆積 した新第三紀中新世の南薩㒶群，第四紀の阿多火哗流より成る。 四万十層群は砂岩, 頁岩の互層よりなり, 地表では春日鉱山の西方に



1. 正会員 春日钎山姝式会社社長
露出する。南薩層群は安山岩質の凝灰岩, 凝灰角磁岩, 溶岩より 構成されるが全体に変質作用を受けプロピライト化しており，春 日鉱山周辺に点在して露出する。阿多火碎流は未変質の石英安山 岩ないし安山岩質の溶結凝灰岩で地表を広く被覆して分布する。

鉱床は南薩層群中に胚胎する塊状含金銀珠酸鉱体である。春日 鉱山鉱区内ではこのような含金銀珄酸鉱体は，本鉱体，第一鉱体， 第二鉱体，第三鉱体，栗カ野鉱体および園見岳鉱体の 6 鉱体が知 られている。このうち最大のものは現在稼行中の本鉱体で $500 \mathrm{~m}$ $\times 150 \mathrm{~m} \times 100 \mathrm{~m}$ の規模を有し，南に急傾斜する。内部構造につい

第1表沿革

\begin{tabular}{|c|c|}
\hline 年 & 事 \\
\hline 明治34年 & 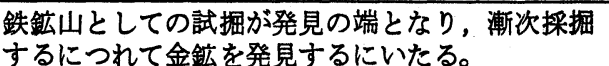 \\
\hline 明治 41 年12月 & $\begin{array}{l}\text { 鹿児島県人今藤矢太夫, 吉村兼高両氏が初めて採 } \\
\text { 掘権を取得乙開登を行い大正 } 2 \text { 年に製鍊開始。 }\end{array}$ \\
\hline 大正 5 年 6 月 & $\begin{array}{l}\text { その後福岡県人阿部元松氏が讓り受けたが再び他 } \\
\text { に鸾渡。 }\end{array}$ \\
\hline 昭和 4 年 4 月 & 日本鉱業株式会社の所有となり本格的開発に着手。 \\
\hline 昭和14年 & $\begin{array}{l}10,000 \mathrm{t} / \text { 月処理の青化製鍊設備の建設に着手し, } \\
\text { 昭和 } 16 \text { 年 } 4 \text { 月完成。 }\end{array}$ \\
\hline 昭和18 & $\begin{array}{l}\text { 金鉱業整備令により帝国鉱発に接収設備解体のう } \\
\text { え転用。 }\end{array}$ \\
\hline 昭和 22年 2 月 & $\begin{array}{l}\text { 帝国鉱発より委託稼行の形式で日本鉱業株式会社 } \\
\text { 採掘開始。 }\end{array}$ \\
\hline $\begin{array}{l}\text { 昭和 } 24 \text { 年11月 } \\
\text { 昭和37年10月 }\end{array}$ & $\begin{array}{l}\text { 日本鉱業株式会社が鉱業権を取得。 } \\
\text { 日本鉱業株式会社の直営から分離して春日鉱山株 } \\
\text { 式会社として発足今日にいたる。 }\end{array}$ \\
\hline
\end{tabular}

\begin{tabular}{|c|c|c|c|c|}
\hline & & 年 & 代 & 産金量 \\
\hline \multirow{2}{*}{\multicolumn{2}{|c|}{ 日本 鉱 業 }} & \multicolumn{2}{|c|}{ 昭和 4 年 18 年 } & 約 $2 \mathrm{t}$ \\
\hline & & \multicolumn{2}{|c|}{ 昭和 22 年 37年 } & 約 $1 \mathrm{t}$ \\
\hline \multicolumn{2}{|c|}{ 春日鉱山 } & \multicolumn{2}{|c|}{ 昭和 37 年 57 年 } & 約 $3 \mathrm{t}$ \\
\hline & & \multicolumn{2}{|r|}{ 計 } & 約 $6 \mathrm{t}$ \\
\hline \multicolumn{5}{|c|}{ 第了表 生 産 量 } \\
\hline 年度 & 鉱 & 量 & $\mathrm{Au}$ 品位 & $\mathrm{Au}$ 量 \\
\hline 53 年度 & & $604 \mathrm{t}$ & $2.3 \mathrm{~g} / \mathrm{t}$ & $147,206 \mathrm{~kg}$ \\
\hline 54 & & 526 & 2.3 & 127,387 \\
\hline 55 & & 187 & 2.3 & 145,820 \\
\hline 56 & & 280 & 2.1 & 154,651 \\
\hline 57 & & 773 & 2.4 & 182,383 \\
\hline
\end{tabular}

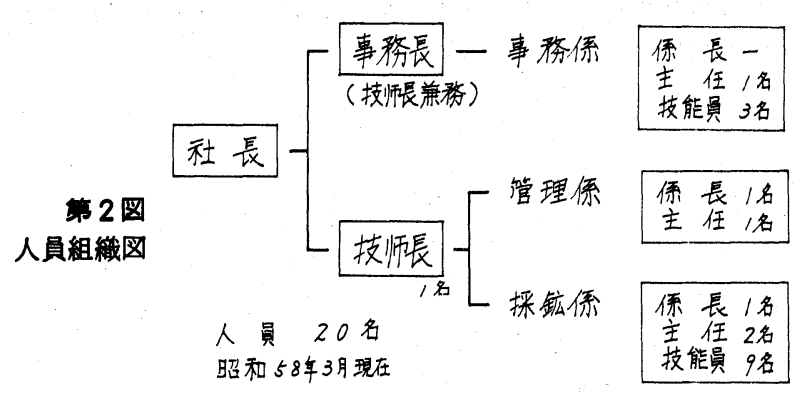




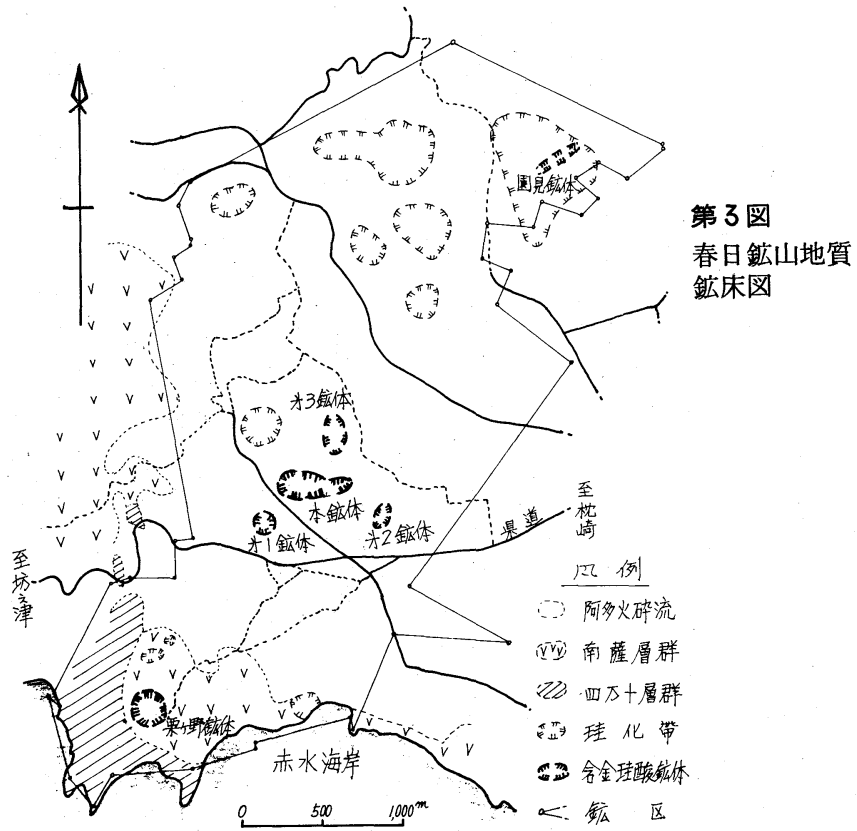

ては北東一南西およびほぼ東西の割目が発達し，これらに沿つて， 石英脈や酸化鉄が生じ, 高品位 $(\mathrm{Au} 2 \sim 30 \mathrm{~g} / \mathrm{t})$ の富鉱部を形成 している。このような富鉱部の集合した部分は鉱体の中心部にあ り，過去において坑内採掘の対象となつた部分である。

本鉱体以外の鉱体では第一鉱体の他栗力野鉱体の極く一部が稼 行された実績をもつが本鉱体に比し小規模である。また第二鉱体， 第三鉱体および園見岳鉱体は低品位, 小規模であり, 稼行の実績 はない。

\section{3. 採掘}

$3 \cdot 1$ 開 坑

戦前, 日本鉱業 (株) 操業時より, 本坑 $0 \mathrm{M}$ (海抜 $90 \mathrm{~m}$ ) を主要 運搬搬出坑道とし, 大切坑 (海拔 $25 \mathrm{~m}$ ) を下部排水坑道とした。

本鉱体は $0 \mathrm{M}$ 上部に $+10 \mathrm{M},+20 \mathrm{M},+30 \mathrm{M},+40 \mathrm{M}$ の中段を

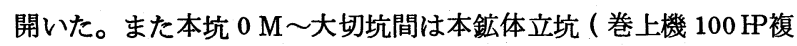
胴）を開さく, $-10 \mathrm{M},-25 \mathrm{M},-40 \mathrm{M},-50 \mathrm{M}$ の各中段を開い

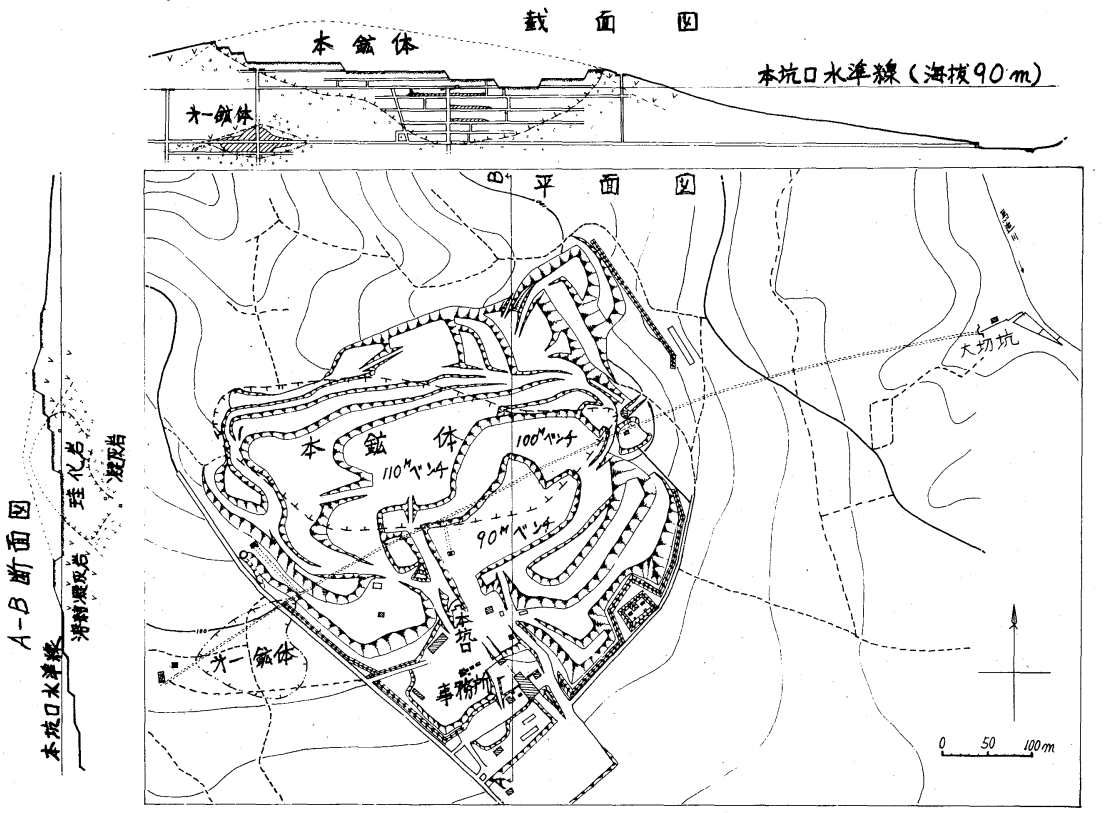

第 4 図 春日鉱山本鉱体の平, 断面図

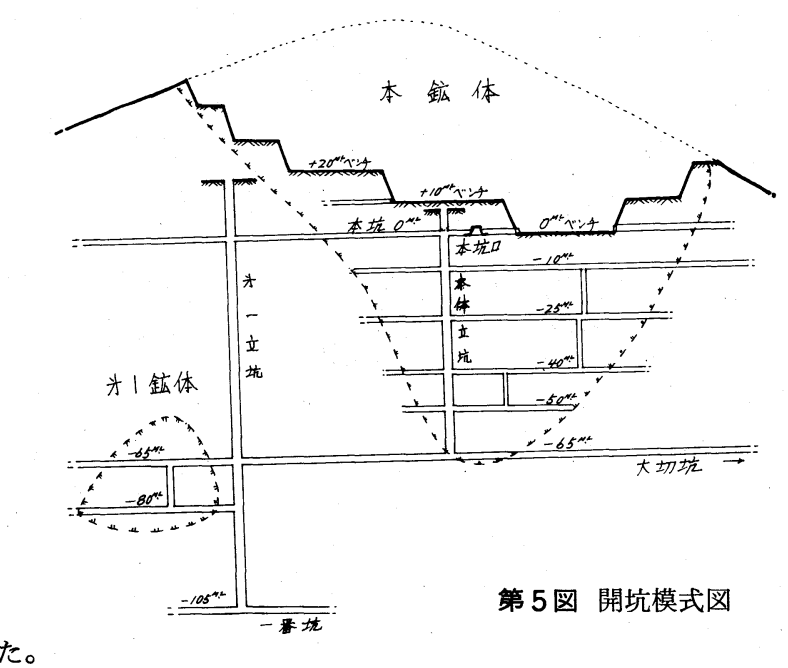

昭和14年に発見された第一鉱体は第一立坑 (巻上機 $40 \mathrm{P}$ 複胴 ) を本坑 $0 \mathrm{M} \sim$ 大切坑から更に一番坑 (海抜- $15 \mathrm{~m}$ ) まで掘下り開 坑した。

$3 \cdot 2$ 坑内採掘

戦前, 戦後復旧に際しても高品位志向の採掘を行なつた。鉱石 は $\mathrm{Au}$ 品位により 1 号鉱 ( $\mathrm{Au} 4.5 \mathrm{~g} / \mathrm{t}$ 以上), 2 号鉱 ( $\mathrm{Au} 3.5$ $\mathrm{g} / \mathrm{t}$ 以上) および 3 号鉱 ( $\mathrm{Au} 2.0 \mathrm{~g} / \mathrm{t}$ 以上) の 3 種類に分類さ れており，本鉱体では抜掘的残柱式空洞掘が，また第一鉱体では トップスライシング，ローカルケービングが行なわれた。

昭和38年 7 月をもつて坑内採掘は全て終了した。

\section{$3 \cdot 3$ 露天掘}

昭和30年から本鉱体上部の低品位鉱採掘のために既設の鉱石立 坑を利用してその周辺を採掘したが，その主力は $+20 \mathrm{M},+30 \mathrm{M}$ および+40Mであつた。

昭和37年，春日鉱山が発足してからは全量を含金珄酸鉱として 販売することとなり, 採掘法を露天掘のみとして大型化を計り, 原価節減に努めた。第一段階として, 昭和39年トラクタショベル および $6 \mathrm{t}$ ダンプトラックの導入を計り露天中央部において+20 $\mathrm{M}$ を基点として $+50 \mathrm{M}$ までを $45^{\circ}$ の傾斜採掘法に切替えた。

昭和 40 年, 珠酸鉱の拡肘に対応して, クローラドリルおよびポ ータブルコンプレッサを採用し，階段式採 掘法に切替えることにより保安, 生産とも に飛躍的に前進し，今日にいたつている。 ベンチは坑内採掘時の開坑に合わせて $0 \mathrm{M}$, $+10 \mathrm{M},+20 \mathrm{M},+30 \mathrm{M},+40 \mathrm{M}$ および+ $50 \mathrm{M}$ であるが将来は一 $25 \mathrm{M}$ まで採掘する計 画である。

$$
\begin{aligned}
& 3 \cdot 4 \text { 採 掘 (現状) } \\
& 3 \cdot 4 \cdot 1 \text { 採掘の規格 } \\
& \text { ベンチの高さ } 10 \mathrm{~m} \\
& \text { ベンチの幅 } 10 \mathrm{~m} \text { 以上 } \\
& \text { ベンチの傾斜 } 70^{\circ} \text { 以内 }
\end{aligned}
$$

最終ピッドスロープを $45^{\circ}$ とする。

$$
3 \cdot 4 \cdot 2 \text { さく孔および発破 }
$$

さく孔機 ドリルマスターDM 25 (インガーソルランド製 )

ダウンザホールハンマ

DHD -350

$\begin{array}{lll}\text { ロッド } & 100 \mathrm{~mm} \phi & 7.6 \mathrm{~m} \times 2 \\ \text { ビット } & 130 \mathrm{~mm} \phi & \text { ボタンビット }\end{array}$




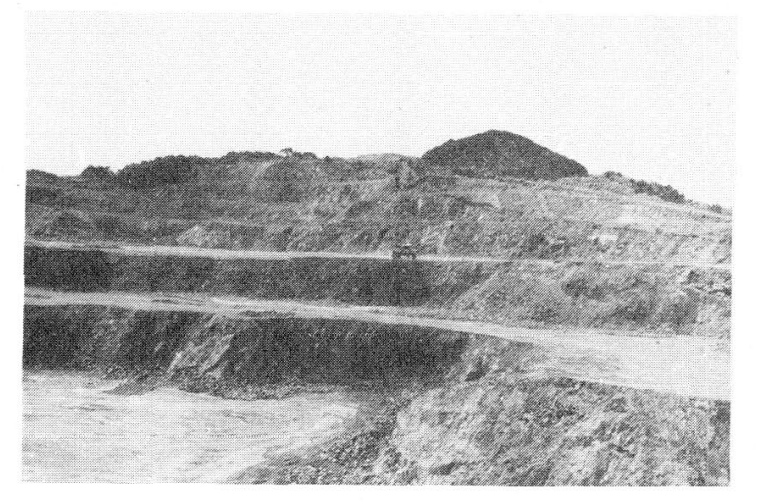

写譻1 露 天 全 景

露天掘への切替後常に省力化, コストダウンを志向して, 発破 の大型化を中心として重機類の導入に努めてきた。

現有重機を第 4 表に示す。

\section{$3 \cdot 4 \cdot 6$ 操業成績}

昭和 57 年度の操業成續を第 5 表に示す。

$$
\text { 4. その他 }
$$

\section{$4 \cdot 1$ 破 碎}

ダンプトラックで粗碎場に運ばれた鉱石は一次，二次のジョー クラッシャにより $50 \mathrm{~mm}$ 以下に破碎され山許貯鉱舎に一時貯鉱さ れる。

\section{4・2 トラック翰送および船積}

山許貯鉱舎から坊津港貯鉱舎 $(1000 \mathrm{t})$ まで約 $6 \mathrm{~km}$ ダンプト ラック（11 t 積，4台）で運搬する。県道はよく整備されたが坊

第 4 表 重 機 一 覧

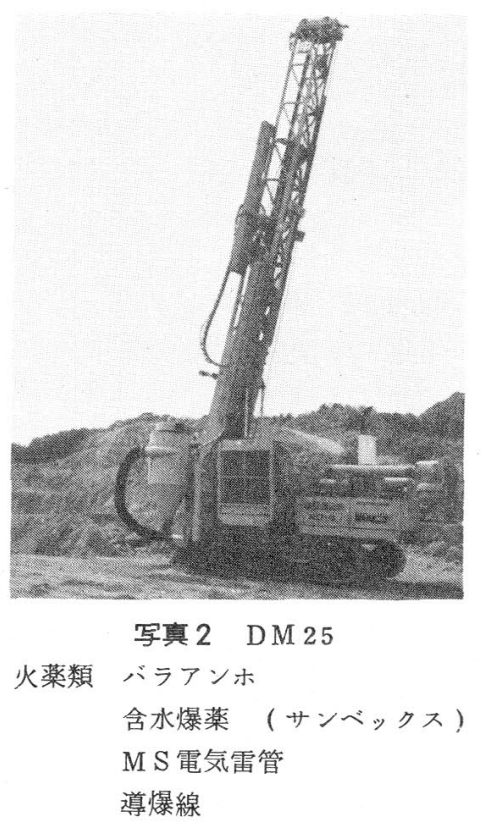

下向 $70^{\circ}$ で $12.5 \mathrm{~m} さ く 孔$ 後, 孔底よりサンベックス, 導爆線, バラアンホ流し込み, サンベックスプライマ, 砂の順に装墤する。 最大抵抗線，孔間隔ともに $7 \mathrm{~m}$ としている。

旧採掘跡等のためD M 25によるさく孔の大型発破が不可能な简 所では全油圧式クローラ HCR-200(ドリフタ HD-200 古河さ く岩機製）によりヶースバイケースのさく孔をする。

$$
\begin{aligned}
& \text { ロッド } 32 \mathrm{~mm} \text { 六角中空 } 4.0 \mathrm{~m} \text { (大同 C R } 5 \text { ) } \\
& \text { スリーブ Tネジ }
\end{aligned}
$$

なお二次発破は大型油圧ブレーカの導入によりほとんど不要と なつた。

\section{$3 \cdot 4 \cdot 3$ 露天運搬}

発破後, バックー(UH-10 日立建機製)により切羽整形, 浮石落としを行なう。その後ブレーカ（YB-3000 油谷重工製） により $500 \mathrm{~mm}$ 以下に大割したものをドーザショベル（D95 S 小 松製作所製) でオフロードダンプトラック（HD-200-2, HD180-4 小松製作所製）に積达み粗秒場投入口まで運ぶ。

$$
3 \cdot 4 \cdot 4 \text { 剩 土 }
$$

剥土は低品位鉱㐨よび鉱体周辺の熔結凝灰岩を対象に実施して いる。剥土の方法，規格は採掘と同様で捨石たい積場に運搬して 処理している。

\begin{tabular}{|c|c|c|}
\hline 型 式 & 仕 & $x-n$ \\
\hline $\mathrm{DM}-25$ & ハソマDHD-350 ビット $130 \mathrm{~mm}$ & インガーソルランド \\
\hline $\mathrm{HCR}-200$ & ドリフタ $\mathrm{HD}-200$ & 古河さく岩機 \\
\hline D 95S & バケット容量 $3.2 \mathrm{~m}^{3}$ & 小松製作 所 \\
\hline D $75 \mathrm{~S}$ & バケット容量 $2.4 \mathrm{~m}^{3}$ & 上 \\
\hline PDR -600 & $\begin{array}{l}\text { 出力 } 183 \mathrm{PS} / 1800 \mathrm{rpm} \\
\text { 吐出量 } 17 \mathrm{~m}^{3} / \mathrm{min} \text { 压力 } 7 \mathrm{~kg} / \mathrm{cm}^{2}\end{array}$ & 北 越 工 業 \\
\hline $\mathrm{UH}-10$ & バケット容量 $1 \mathrm{~m}^{3}$ & 日 立 建 機 \\
\hline $\mathrm{UH}-06$ & バケット容量 $0.45 \mathrm{~m}^{3}$ & 上 \\
\hline $\mathrm{HD}-200-2$ & $20 \mathrm{t}$ 積 & 小松製作所 \\
\hline $\mathrm{HD}-180-4$ & $18 \mathrm{t}$ 積 & 同 \\
\hline $\mathrm{YB}-3000$ & YS 750-2 型に搭載 & 油谷重工 \\
\hline
\end{tabular}

本鉱体露天掘開始時の計画剝土比は約 0.7 であつたが現状での 所要剶土比は約 0.3 となつている。

\begin{tabular}{|c|c|c|}
\hline & 採掘 $\mathrm{t}$ 当り & 採鉣 $\mathrm{t}$ 当り \\
\hline 薬 & $0.056 \mathrm{~kg} / \mathrm{t}$ & $0.090 \mathrm{~kg} / \mathrm{t}$ \\
\hline 管 & 0.015 個 $/ \mathrm{t}$ & 0.023 個/ t \\
\hline ビット, ロッド & $6 \mathrm{M} / \mathrm{t}$ & $9 \mathrm{H} / \mathrm{t}$ \\
\hline さく岩機部品 & 3 円 $/ \mathrm{t}$ & $4 \mathrm{~m} / \mathrm{t}$ \\
\hline 機 械車輛部品 & 17 円 $/ \mathrm{t}$ & $22 \mathrm{H} / \mathrm{t}$ \\
\hline 料 油 & $0.56 \ell / t$ & $0.90 \ell / t$ \\
\hline 直 接 工 数 & 0.007 工 $/ \mathrm{t}$ & $0.007 \mathrm{I} / \mathrm{t}$ \\
\hline 間 接 工 数 & $0.002 \mathrm{I} / \mathrm{t}$ & $0.011 \mathrm{I} / \mathrm{t}$ \\
\hline
\end{tabular}

$$
3 \cdot 4 \cdot 5 \text { 重機の導入 }
$$

第 5 表 操業成績 (原単位)

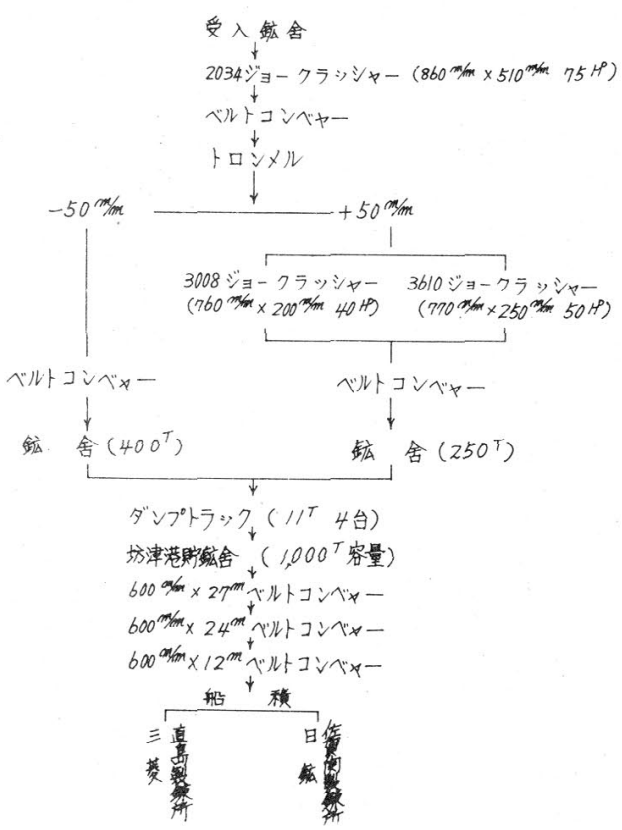

第 6 図 破碎運輸系統図 
津町内は人家が密集し今後道路整備の見通しは暗く，そのためダ ンプトラックの大型化は限界である。

貯鉱舎からはスライド式ベルトコンベヤを含む積込装置で船積 みし, 海路, 販売先へ輸送する。
坊津港は天然の良港であるが東シナ海の冬季の季節風によるト ラブルに悩まされてきたがこれも近年は 1500 七積鉱石船（日本マ リン(株))が就航するようになり大幅に解消した。 第 6 図に破砕から販売までの操業系統図を示す。

\section{Kasuga Mine}

by Fuyuo ITOKAWA

Kasuga mine is located at Makurazaki city, southern part of Kagoshima prefecture and its deposits are massive silicate ore containing gold and silver minerals.

Annual production of the mine is 76,000 tons of crude ore $(2.3 \mathrm{~g} / \mathrm{t} \mathrm{Au})$ and mining method is bench cut.

This paper describes on the following points

(1) Geology and mineral deposits

(2) Mining operation

1) opening, 2) underground mining, 3) bench cut mining, 4) operation practice

(3) Others

1) crushing, 2) transportation

鉱山資料館だより

\section{[2]}

\section{-別子銅山記念館}

所在地 $\bar{T} 792$ 新居浜市角野新田町 3-13

電 話 $0897-41-2200$

別子銅山の意義を永く後世に伝えるために，住友グループ各社 の協力によつて建設された資料館である。

主要な展示は, 泉屋, 歷史, 地質・鉱床, 生活・風俗, 技術の 各コーナー, それに大規模な坑道模型, 屋外には別子 1 号機関車, トロリー電車, 鉱車, かご電車, 電気機関車が展示されている。

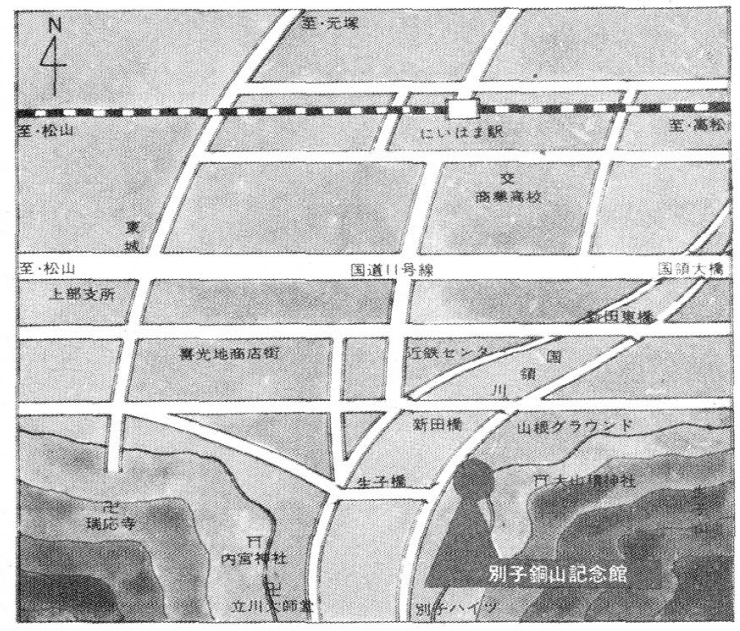

記念館自体が，青緑の山腹に同様な傾斜をもつて構築されてお り，半地下式というか，鉱山にふさわしい建物となつている。 坑道模型は, 約 300 年間に海面下 $1,000 \mathrm{~m}$ まで掘り進んだ全容を, 一見して把握できるよう製作されており,まことに出色のもので ある。絵図，屏風等をはじめご用銅の棹銅，その他国内向けの丁 銅，丸銅等が美しい酸化銅の色目を鮮やかに呈していて印象深い。 入場は無料で, 月曜, 祝日, 年末年始が休館となる。交通は国 鉄新居浜駅より新田市民グランド行きバス20分。
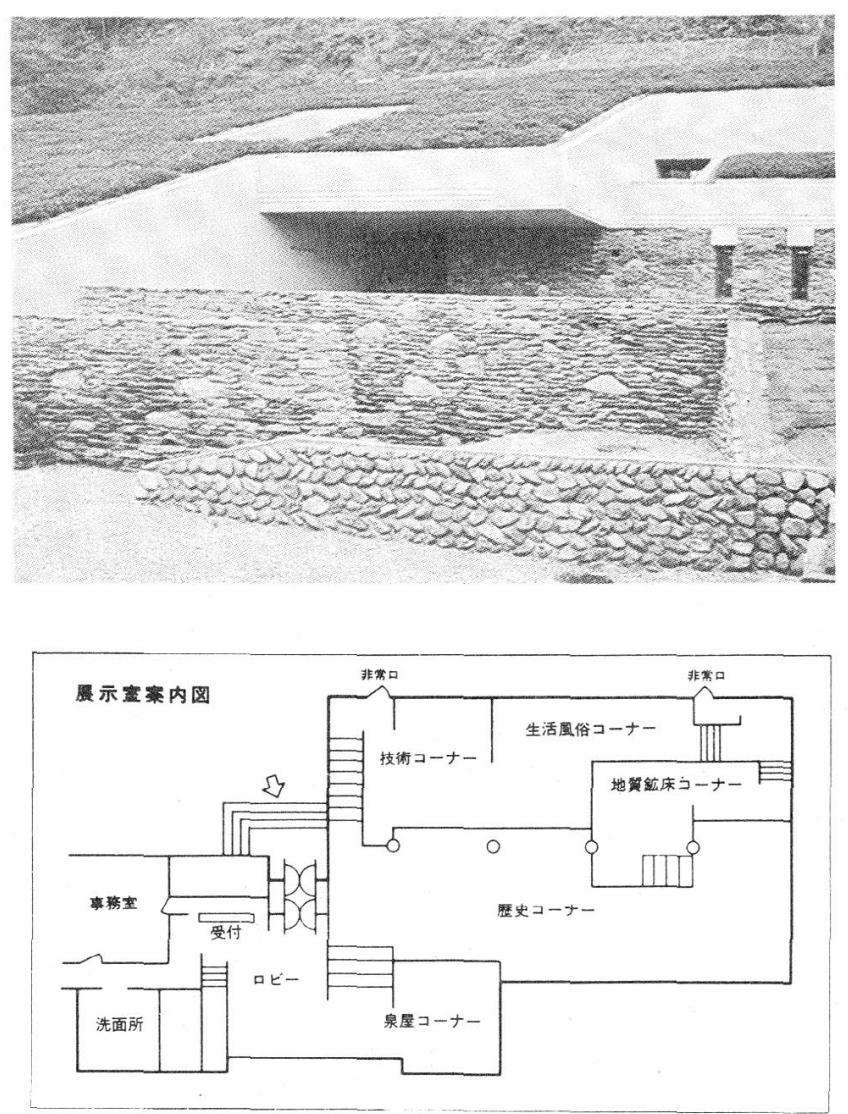